\title{
Pengaruh Waktu Penyiangan Gulma Terhadap Pertumbuhan Dan Produksi Tanaman Jagung Manis (Zea mays L. saccharata)
}

\author{
Chelsea Maria Inanosa, Akhmad Ali \\ Universitas Muhammadiyah Sorong
}

\begin{abstract}
Abstrak
Penelitian ini bertujuan mengetahui pengaruh waktu pengendalian gulma terhadap pertumbuhan dan hasil tanaman jagung manis. Penelitian ini dilaksanakan di Kebun Petani Kelurahan Klamana Distrik Sorong Timur Kota Sorong.

Penelitian ini berlangsung mulai dari bulan Agustus sampai dengan bulan Oktober, 2017. Penelitian ini dilakukan dalam bentuk percobaan yang disusun berdasarkan Rancangan Acak Kelompok (RAK) dengan 4 kali perlakuan dan 3 kali ulangan sebagai berikut : G0 = Bebas gulma. G1 = Bergulma s/d 20 HST. G2 = Bergulma s/d 40 HST, G3 = Bergulma s/d 60 HST. Data hasil penelitian dianalisis menggunakan analisis ragam dan apabila berbeda nyata maka akan dilanjutkan dengan Uji Beda Nyata Tetap (BNT) pada taraf 0.05 dan $0.01 \%$. Hasil penelitian menunjukan bahwa Perlakuan gulma (G1) berpengaruh nyata terhadap tanaman saat pertumbuhan vegetatif dan perlakuan (G2) berpengaruh nyata terhadap tanaman jagung manis pada saat pertumbuhan generative tanaman jagung manis.Perlakuan penyiangan gulma (G1) pada tanaman jagung manis hingga waktu sampai dengan 20 hari setelah tanam (HST) berpengaruh terhadap tinggi tanaman jagung manis umur 15 HST $(97.46 \mathrm{~cm}), 30 \mathrm{HST}(164.94 \mathrm{~cm})$ dan 45 HST $(223.18 \mathrm{~cm})$ dan jumlah daun pada umur 15 HST (18.17 helai), 30 HST (12.83 helai) dan 45 HST (14.33 helai). Sedangkan perlakuan bergulma (G2) hingga waktu 40 hari setelah tanam (HST) berpengaruh terhadap komponen dimeter tongkol $(6.19 \mathrm{~cm})$, panjang tongkol $(23.85 \mathrm{~cm})$, berat tongkol $(125.75 \mathrm{gr})$ dan produksi tongkol (4.98 kg/petak).
\end{abstract}

Kata Kunci : Penyiangan, gulma, jagung manis

\section{PENDAHULUAN}

Tanaman jagung manis (Zea mays sacarrata L.) merupakan salah satu tanaman pangan yang banyak dibudi dayakan di dunia, termasuk di Indonesia. Tanaman jagung selain digunakan sebagai bahan pangan sebagian masyarakat Indonesia, juga digunakan sebagai bahan baku untuk pakan ternak. Tanaman jagung adalah tanaman yang relatif mudah dibudidayakan karena tidak terlalu banyak membutuhkan persyaratan khusus, sehingga tanaman jagung banyak ditanam di Indonesia (Adisarwanto dan Widyastuti, 2009). Menurut Badan Pusat Statistik (2016) , produksi jagung di Indonesia pada tahun 2015 sebesar 19,37 juta ton.

Produksi ini mengalami peningkatan dari tahun sebelumnya yang sebesar 17,64 juta ton. Meskipun demikian, saat ini Indonesia masih melakukan impor jagung sebesar 3,2 juta ton dari luar negeri. Hal ini dilakukan untuk memenuhi kebutuhan jagung di Indonesia yang setiap tahunnya mengalami peningkatan. Hingga saat ini produksi jagung di Indonesia belum dapat memenuhi kebutuhan jagung nasional karena rendahnya produktivitas lahan. Berbagai factor menjadi penyebabrendahnya produksi jagung dan salah satunya adalah keberadaan gulma yang mengganggu pertumbuhan 
tanaman jagung. Pengendalian gulma merupakan salah satu solusi dalam penyelesaian permasalahan gulma agar tidak terjadi perebutan hata diantara keduanya, terutama pada fase kritis pertumbuhan tanaman jagung yaitu sejak awal tanaman hingga 21 hari (Palungkun dan Budiarti., 2002).

Selama pertumbuhannya disekitar jagung manis (Zea mays sacarrata L.) selalu saja ada tumbuhan penggagu atau gulma yang selalu bersaing dalam merebut makanan disekitarnya. Keberadaan gulma di sekitar tanaman budidaya dapat menyebabkan kerugian yang besar walaupun berlangsung secara perlahan, gulma dapat bersaing untuk mendapatkan sarana tumbuh seperti cahaya, air, dan unsur hara lainnya (Rizal. 2004).

Marselia crenata, Cynodon dactylon, Echinochloa colona, Comellina sp, Alathenanthera phyloxeraides, Cyperus rotundus, ,Amaranthus spinosus, Ageratum conyzoides, dan Eleusine indica, serta Protulaca olera ceae merupakan jenis-jenis gulma yang paling penting terdapat pada tanaman jagung (Dirjenbun (2006) Keragaman gulma ini menyebabkan keberadaannya menjadi ancaman yang perlu dikendalikan secepat mungkin.

Selain menggunakan pengendalian secara fisik, kini tidak sedikit petani yang menggunakan herbisida. Disamping mudah, penggunaan herbisida juga lebih cepatdalam memberantas gulma. Penggunaan herbisida merupakan cara yang paling mudah dan murah karena selain harga yang murah, herbisida mampu mengendalikan sampai ke akar-akarnya.

Menurut Tjitrosoedirdjo, dkk. (2004), persaingan antara gulma dan tanaman dipengaruhi oleh waktu atau lamanya tanaman berada dan bersaing dengan gulma. Dari pernyataan Sukman dan Yakup (2005), yaitu bahwa hadirnya gulma pada awal hidup tanaman akan sangat berpengaruh terhadap tanaman pada fase tersebut tanaman sangat peka terhadap kehadiran gulma, fase ini disebut fase kritis tanaman.

Jika gulma tumbuh di lahan budidaya pada fase ini menyebabkan tanaman akan kalah bersaing dengan gulma. Oleh karena itu, pada fase tersebut perlu dilakukan pengendalian gulma. Seperti yang dijelaskan, dkk (2004) dalam konsep kompetisi gulma dan tanaman, bahwa semakin tinggi pertumbuhan populasi gulma yang berada di lahan pertanaman jagung, maka hasil yang diperoleh tanaman yang dibudidayakan akan semakin menurun.

Berdasarkan uraian tersebut diatas, maka perlu dilakukan penelitian tentang Pengendalian gulma yang terdapat pada tanaman jagung dengan cara melakukan penyiangan pada berbagai waktu perlakuan pada fase pertumbuhan tanaman jagung hingga mencapai produksi.

\section{METODOLOGI PENELITIAN}

Penelitian ini dirancang dalam bentuk percobaan berdasarkan Rancangan Acak Kelompok (RAK) dengan 4 kali perlakuan dan 3 kali ulangan sebagai berikut : G0 = Bebas gulma G1 = Bergulma s/d 20 HST G2 = Bergulma s/d 40 HST G3 = Bergulma s/d 60 HST Masing-masing perlakuan diulang sebanyak 3 kali sehingga di perlakuan terdapat $4 \times 3=12$ perlakuan. Setiap petak perlakuan terdapat 16 tanaman dan masing masing perlakuan terdapat 6 sampel sehingga keseluruhan dibutuhkan 12 × $6=72$ tanaman sampel

\section{Pelaksanaan Penelitian}

1. Pengolahan tanah

Tanah diolah dua kali dengan menggunakan cangkul, sesudah itu dibuat bedengan dengan ukuran $1.2 \mathrm{~m}$ x $2 \mathrm{~m}$ sebanyak 12 petak. Tinggi bedengan $30 \mathrm{~cm}$. Jarak antar 
ulangant $40 \mathrm{~cm}$ dan jarak antar petak $50 \mathrm{~cm}$ sekaligus berfungsi sebagai saluran drainase. .

2. Penanaman dan penyulaman

Penanaman benih dilakukan dengan cara tugal sedalam 2-3 cm, dengan jarak tanam $70 \mathrm{~cm}$ x $20 \mathrm{~cm}$. Pada setiap lubang ditanam 2 benih jagung manis kemudian ditutupi kembali dengan tanah. Penyulaman dan penjarangan dilakukan satu seminggu setelah tanam dengan mengganti tanaman yang telah mati atau terlambat tumbuh dengan bibit tanaman yang telah si sipakan.

3. Pemupukan

Pupuk yang diberikan untuk adalah pupuk organik bokashi kotoran sapi yang diberikan seminggu setelah tanaman dengan cara ditabur pada permukaan bedengan kemudian diratakan hingga menyatu dengan tanah dan pupuk anorganik NPK mutira diberikan 3 kali selama pertumbuhan yaitu pada umur tanaman 15, 3045 HST.

4. Pengendalian gulma

Perlakuan pengendalian gulma dilakukan pada tanaman sampai 20, 40 dan 60 hari setelah tanam (HST), dan dilakukan secara mekanis dengan cara pencabutan dengan menggunakan. Tangan -manual (hand pulling),

5. Panen

Jagung manis tergolong jagung yang berumur genjah. Umur panen tanaman ini tergantung pada jenisnya. Umumnya jagung manis siap dipanen pada umur 70-75 hari setelah tanam. Saat panen yang tepat adalah bila rambut jagung manis telah berwarna cokelat dan tongkolnya telah berisi penuh, dan dilakukan pada waktu pagi hari.

\section{Variabel Pengamatan}

Pengamatann dilakukan terhadap beberapa variable pertumbuhan dan produksi dari tanaman jagung diantaranya adalah :

1. Tinggi tanaman $(\mathrm{cm})$, diukur dari pangkal batang sampai ujung daun tertinggi yang ditegakan. Pengamtan pada umur 15, 30 dan 45 HST

2. Diameter tongkol $(\mathrm{cm})$, diukur diameter tongkol pada bagian tengah tongkol yang telah dikupas kelobotnya dengan menggunakan jangka sorong.

3. Panjang tongkol $(\mathrm{cm})$, diukur panjang tongkol dari pangkal buah sampai ujung buah setelah panen

4. Berat tongkol tanpa dengan klobot (g), dilakukan dengan menimbang tongkol dengan kelobotnya setelah panen.

5. Produksi tongkol perpetak (kg), Dihitung produksi tongkol perpetak dilakukan setalah panen dengan menggunakan timbangan duduk $\mathrm{F}$.

\section{Analisa Data}

Data hasil penelitian dianalisis menggunakan analisis ragam dan apabila berbeda nyata maka akan dilanjutkan dengan uji Uji Beda Nyata Tetap (BNT) pada taraf $0.05 \%$.

\section{HASIL DAN PEMBAHASAN}

\section{Tinggi Tanaman}

Tinggi tanaman dan sidik ragamnya ditampilkan pada Tabel Lampiran 1a, 1b, 2a, 2b, 3a, dan 3b. Hasil Sidik ragam terlihat bahwa penyiangan gulma berpengaruh nyata pada tinggi tanaman. Rerata berpengaruh nyata pada umur 4, 6 dan 8 MST dapat dilihat pada tabel 1. 
Tabel 1. Rata-rata tinggi tanaman (cm) umur 15, 30 dan 45 HST

\begin{tabular}{lccc}
\hline \multirow{2}{*}{ Perlakuan } & \multicolumn{3}{c}{ Umur (Hari) } \\
\cline { 2 - 4 } & 15 HST & $30 \mathrm{HST}$ & $45 \mathrm{HST}$ \\
\hline $\mathrm{G}_{0}=$ Bebas gulma & $93.06^{\mathrm{b}}$ & $150.73^{\mathrm{c}}$ & $208.64^{\mathrm{b}}$ \\
$\mathrm{G}_{1}=$ Bergulma s/d 20 HST & $97.46^{\mathrm{a}}$ & $164.94 \mathrm{a}$ & $223.18^{\mathrm{a}}$ \\
$\mathrm{G}_{2}=$ Bergulma s/d 40 HST & $96.20^{\mathrm{a}}$ & $161.71^{\mathrm{a}}$ & $221.31^{\mathrm{a}}$ \\
$\mathrm{G}_{3}=$ Bergulma s/d 60 HST & $94.94^{\mathrm{a}}$ & $157.09^{\mathrm{b}}$ & $218.14^{\mathrm{a}}$ \\
\hline $\mathrm{NP}_{\mathrm{BNT}}$,05 & 2.77 & 5.21 & 9.29 \\
\hline
\end{tabular}

Keterangan : Angka-angka yang diikuti huruf yang sama pada kolom menunjukan tidak berbeda nyata pada taraf uji $\mathrm{a}=0,05$

Tabel 1 menunjukkan bahwa tinggi tanaman pada perlakuan bergulma s/d 20 HST (G1) menghasilkan rata-rata tanaman tertinggi pada umur $15 \mathrm{HST}(97,46 \mathrm{~cm}), 30 \mathrm{HST}$ $(164,94 \mathrm{~cm})$ dan Umur 45 HST $(223,18 \mathrm{~cm})$ dan berbeda nyata dengan perlakuan lainnya pada umur 15, 30 dan 45 HST, tetapi berbeda tidak nyata dengan perlakuan bergulma (G2) dan (G3). Gambaran pertumbuhan tinggi tanaman tanaman jagung dari perlakuan penyiangan gulma dapat dilihat pada gambar 1 .

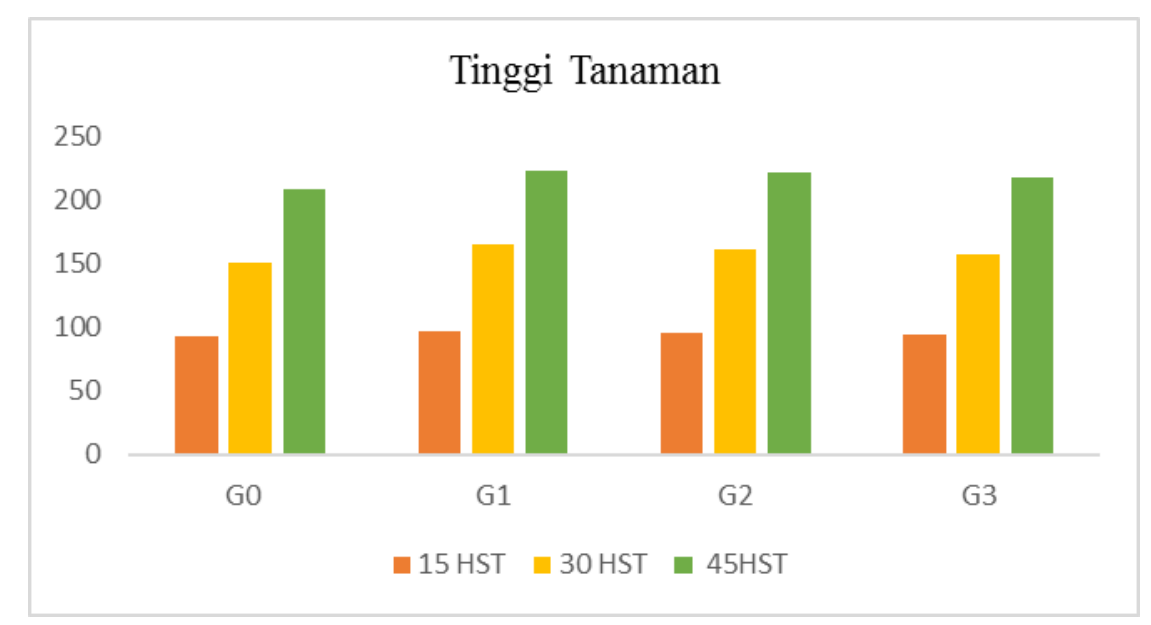

Gambar 1. Rata-rata tinggi tanaman pada pengamatan 15 HST, 30 HST dan 45 HST.

\section{Jumlah Daun}

Jumlah daun tanaman dan sidik ragamnya disajikan pada Tabel Lampiran 4a, 4b, $5 \mathrm{a}, 5 \mathrm{~b}, 6 \mathrm{a}, 6 \mathrm{~b}$. Sidik ragam menunjukkan bahwa penyiangan gulma berpengaruh nyata terhadap jumlah daun tanaman umur 15, 30 dan 45 HST

Tabel 2. Rata-rata jumlah daun (helai) umur 15, 30 dan 45 HST

\begin{tabular}{|c|c|c|c|}
\hline \multirow{2}{*}{ Perlakuan } & \multicolumn{3}{|c|}{ Umur (Hari) } \\
\hline & $15 \mathrm{HST}$ & $30 \mathrm{HST}$ & 45HST \\
\hline $\mathrm{G}_{0}=$ Bebas gulma & $7.56^{\mathrm{b}}$ & $10.67^{b}$ & $12.61^{\mathrm{c}}$ \\
\hline $\mathrm{G}_{1}=$ Bergulma s/d $20 \mathrm{HST}$ & $8.17^{\mathrm{a}}$ & $12.83^{\mathrm{a}}$ & $14.33^{\mathrm{a}}$ \\
\hline $\mathrm{G}_{2}=$ Bergulma s/d $40 \mathrm{HST}$ & $8.00^{\mathrm{a}}$ & $12.17^{\mathrm{a}}$ & $14.11^{\mathrm{a}}$ \\
\hline $\mathrm{G}_{3}=$ Bergulma s/d $60 \mathrm{HST}$ & $7.67^{\mathrm{a}}$ & $11.44^{\mathrm{a}}$ & $13.67^{\mathrm{b}}$ \\
\hline $\mathrm{NP} \mathrm{BNT}_{0,05}$ & 0.37 & 1.44 & 0.45 \\
\hline
\end{tabular}

Keterangan : Keterangan : Angka-angka yang diikuti huruf yang sama pada kolom menunjukan tidak berbeda nyata pada taraf uji $a=0,05$

Tabel 2 menunjukkan bahwa perlakuan jumlah daun tanaman pada perlakuan bergulma s/d 20 HST (G1) menghasilkan rata-rata jumlah daun terbanyak pada umur 15 
HST (8,17 helai), 13 HST (12, 83 helai) dan Umur 45 HST 14,33 helai) tetapi berbeda tidak nyata dengan perlakuan bergulma (G2) dan (G3) pada umur 15, 30 dan 45 HST dan berbeda nyata dengan perlakuan bergulma lainnya dan bebas gulma. Rata-rata pertumbuhan jumlah daun dapat dilihat pada gambar 2 .

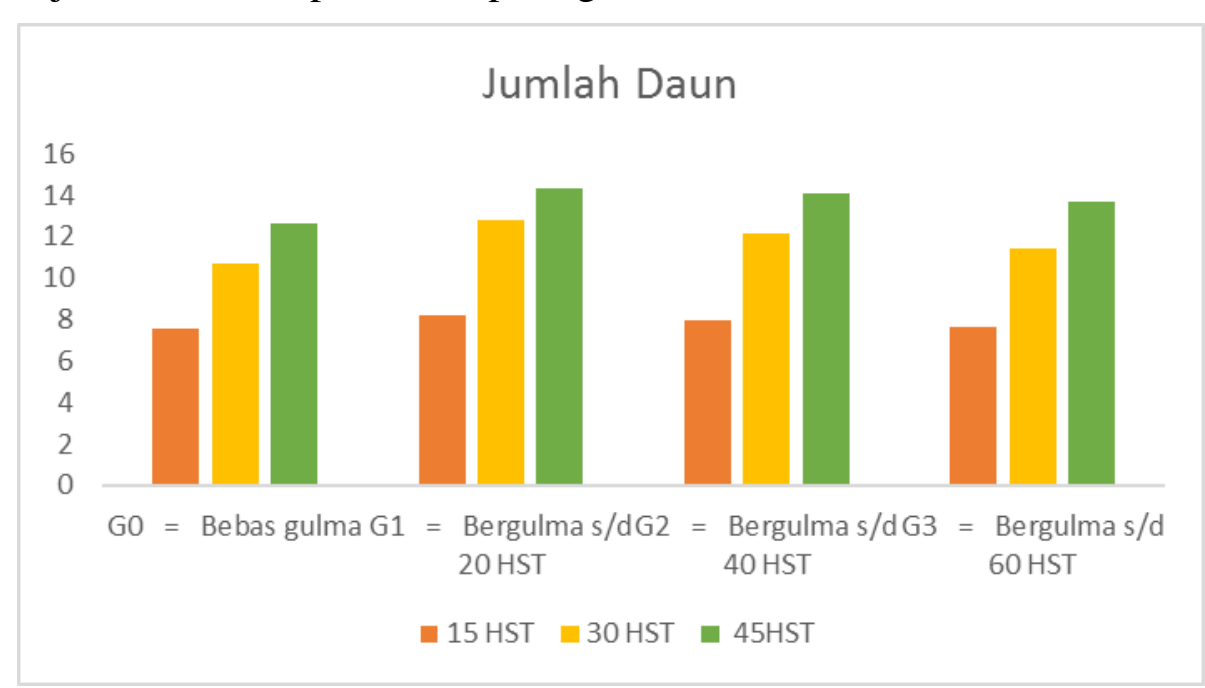

Gambar 2. Rata-rata pertumbuhan jumlah daun pada pengamatan umur 15 HST, 30 HST dan 45 HST

\section{Diameter Tongkol}

Diameter tongkol dan sidik ragamnya disajikan pada Tabel Lampiran 7a dan 7b. Sidik ragam menunjukkan bahwa penyiangan gulma berpengaruh sangat nyata terhadap diameter tongkol.

Tabel 3. Rata-rata diameter tongkol $(\mathrm{cm})$

\begin{tabular}{lcc}
\hline \multicolumn{1}{c}{ Perlakuan } & Rata-rata & NP BNT $_{0,05}$ \\
\hline $\mathrm{G}_{0}=$ Bebas gulma & $5.18^{\mathrm{b}}$ & 0.1837 \\
$\mathrm{G}_{1}=$ Bergulma s/d 20 HST & $6.01^{\mathrm{a}}$ & \\
$\mathrm{G}_{2}=$ Bergulma s/d 40 HST & $6.19^{\mathrm{a}}$ & \\
$\mathrm{G}_{3}=$ Bergulma s/d 60 HST & $5.37^{\mathrm{a}}$ & \\
\hline
\end{tabular}

Keterangan : Keterangan : Angka-angka yang diikuti huruf yang sama pada kolom menunjukan tidak berbeda nyata pada taraf uji $a=0,05$

Tabel 3 menunjukkan bahwa perlakuan gulma s/d 40 HST (G2) menghasilkan rata-rata diameter tongkol yang terlebar $(6,19 \mathrm{~cm})$ dan berbeda nyata dengan tanpa perlakuan (bebas gulma), tetapi berbeda tidak berbeda nyata dengan perlakuan gulma 20 HST (G1) dan 60 HST(G3). Gambaran pertumbuhan diameter tongkol dapat dilihat pada gambar 3 . 


\section{Median Volume 11 Nomor 2 Bulan Juni 2019}

Doi http://doi.org/md.v11i2.587

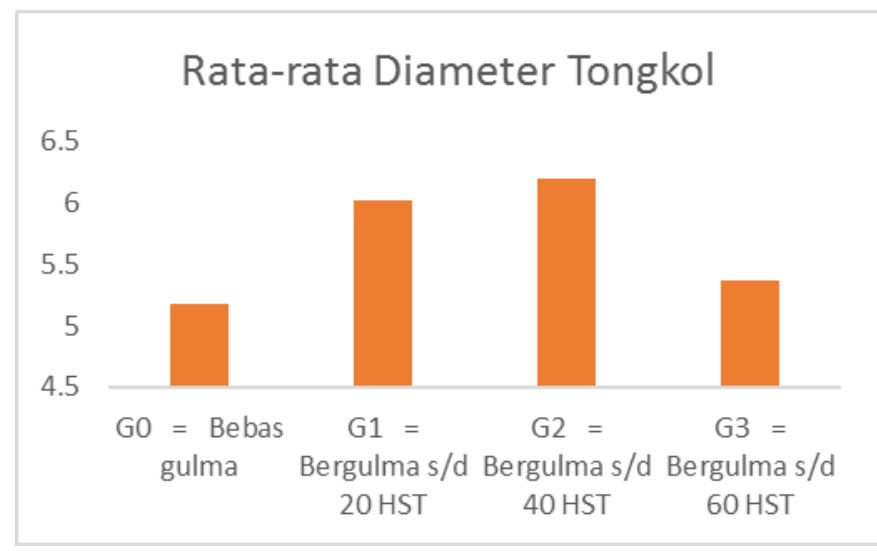

Gambar 3. Rata-rata Pertumbuhan Diameter Tongkol

\section{Panjang Tongkol}

Panjang tongkol dan sidik ragamnya disajikan pada Tabel Lampiran 8a dan 8b. Sidik ragam menunjukkan bahwa penyiangan gulma sangat berpengaruh nyata terhadap diameter tongkol.

Tabel 4 Rata-rata panjang tongkol $(\mathrm{cm})$

\begin{tabular}{lcc}
\hline \multicolumn{1}{c}{ Perlakuan } & Rata-rata & NP BNT $_{0,05}$ \\
\hline $\mathrm{G}_{0}=$ Bebas gulma & $22.64^{\mathrm{b}}$ & 0.7708 \\
$\mathrm{G}_{1}=$ Bergulma s/d 20 HST & $23.66^{\mathrm{a}}$ & \\
$\mathrm{G}_{2}=$ Bergulma s/d 40 HST & $23.85^{\mathrm{a}}$ & \\
$\mathrm{G}_{3}=$ Bergulma s/d 60 HST & $22.83^{\mathrm{b}}$ & \\
\hline
\end{tabular}

Keterangan : Keterangan : Angka-angka yang diikuti huruf yang sama pada kolom menunjukan tidak berbeda nyata pada taraf uji a $=0,05$

Tabel 4 menunjukkan bahwa perlakuan penyiangn bergulma s/d 40 HST (G2) menghasilkan rata-rata tongkol jagung terpanjang $(23,85 \mathrm{~cm})$ dan berbeda nyata perlakuan bergulmam lainnya, tetapi tidak berbeda nyata dengan perlakuan bergulma (G1). Gambaran pertumbuhan panjang tongkol pada tanaman jagung dapat dilihat pada gambar 4.

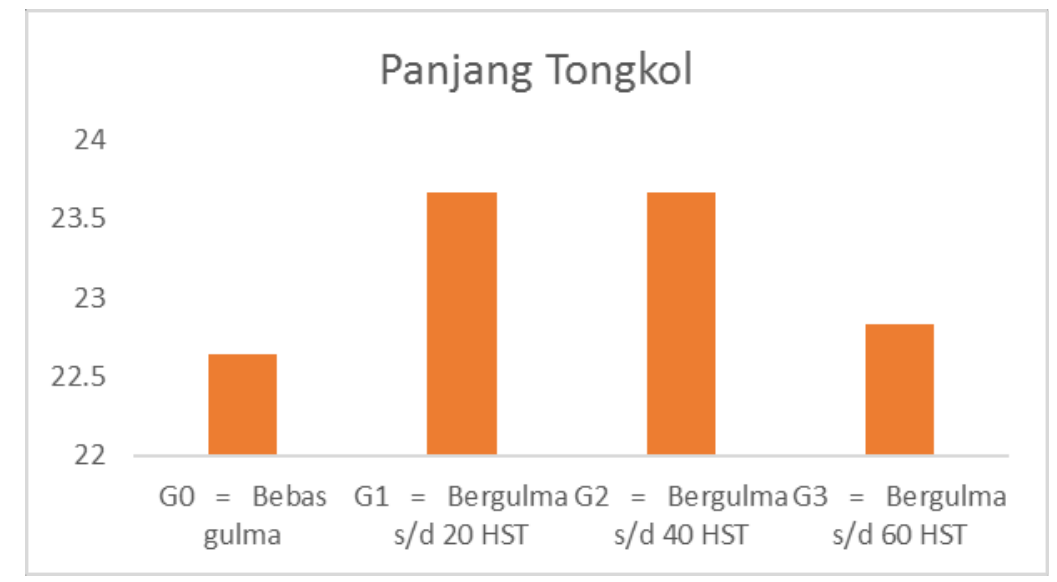

Gambar 4. Rata-rata Panjang tongkol

\section{Berat Tongkol dengan Klobot}

Berat tongkol dan sidik ragamnya disajikan pada Tabel Lampiran 9a dan 9b. Sidik 


\section{Median Volume 11 Nomor 2 Bulan Juni 2019}

Doi http://doi.org/md.v11i2.587

ragam menunjukkan bahwa penyiangan gulma sangat berpengaruh nyata terhadap diameter tongkol.

Tabel 5. Rata-rata berat tongkol $(\mathrm{cm})$

\begin{tabular}{llc}
\hline \multicolumn{1}{c}{ Perlakuan } & Rata-rata & NP BNT $_{0,05}$ \\
\hline $\mathrm{G}_{0}=$ Bebas gulma & $120.16^{\mathrm{c}}$ & 3.8476 \\
$\mathrm{G}_{1}=$ Bergulma s/d 20 HST & $124.58^{\mathrm{b}}$ & \\
$\mathrm{G}_{2}=$ Bergulma s/d 40 HST & $125.75^{\mathrm{a}}$ & \\
$\mathrm{G}_{3}=$ Bergulma s/d 60 HST & $125.08^{\mathrm{b}}$ & \\
\hline
\end{tabular}

Keterangan : Keterangan : Angka-angka yang diikuti huruf yang sama pada kolom menunjukan tidak berbeda nyata pada taraf uji $\mathrm{a}=0,05$

Tabel 5 menunjukkan bahwa perlakuan penyiangn bergulma s/d 40 HST (G2) menghasilkan rata-rata berat tongkol terlebar $(125,75 \mathrm{~cm})$ dan berbeda nyata dengan perlakuan bergulma lainnya dan tanpa perlakuan (G0), sedangkan perlakuan bergulma 60 HST (G30 dan 20 HST (G1) berbeda tidak nyata. Gambaran rata-rata-pertumbuhan berat tongkol dapat dilihat pada gambar 5 .

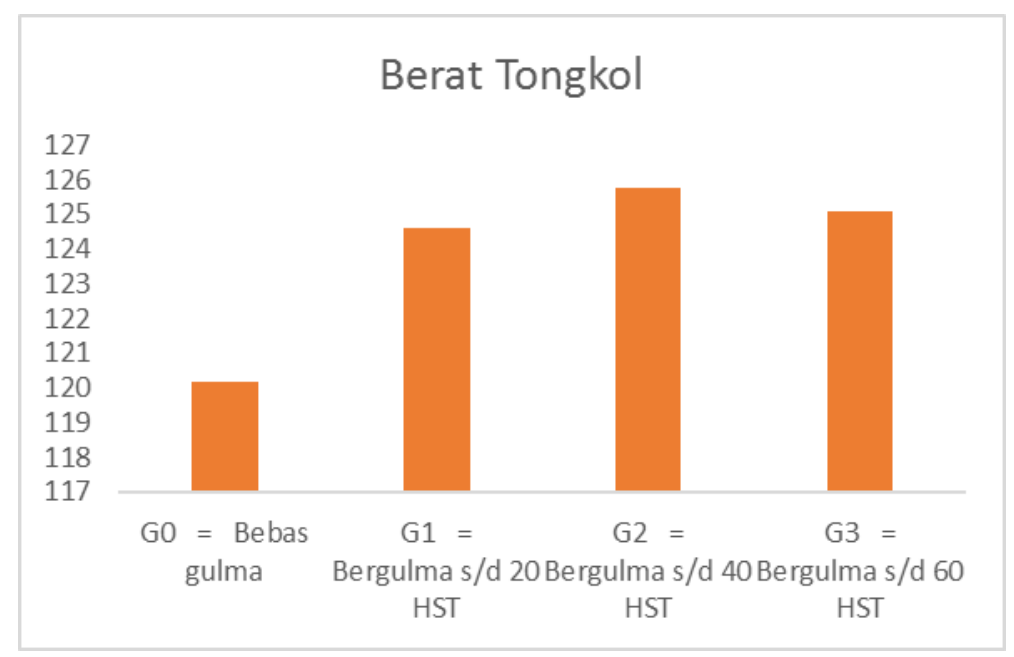

Gambar 5. Berat Tongkol Pada Tanaman Jagung

\section{Produksi}

Produksi tanaman kg/petak serta sidik ragamnya disajikan pada Tabel Lampiran 10a, 10b. $11^{\mathrm{a}}$ dan $11 \mathrm{~b}$. Sidik ragam menunjukkan bahwa perlakuan gulma berpengaruh nyata terhadap produksi jagung $\mathrm{kg} /$ petak Tabel 6. Rata-rata produksi tanaman perpetak

\begin{tabular}{|c|c|c|}
\hline Perlakuan & Rata-rata produksi & $\mathrm{NP} \mathrm{BNT}_{0,05}$ \\
\hline $\mathrm{G}_{0}=$ Bebas gulma & $3.59^{\mathrm{b}}$ & 0.6817 \\
\hline $\mathrm{G}_{1}=$ Bergulma s/d $20 \mathrm{HST}$ & $4.72^{\mathrm{a}}$ & \\
\hline $\mathrm{G}_{2}=$ Bergulma s/d $40 \mathrm{HST}$ & $4.98^{\mathrm{a}}$ & \\
\hline $\mathrm{G}_{3}=$ Bergulma s/d $60 \mathrm{HST}$ & $4.44^{\mathrm{b}}$ & \\
\hline
\end{tabular}

Keterangan : Keterangan : Angka-angka yang diikuti huruf yang sama pada kolom menunjukan tidak berbeda nyata pada taraf uji $a=0,05$

Tabel 8 menunjukkan bahwa perlakuan bergulma s/d 40 HST (G2) menghasilkan rata-rata produksi tanaman tertinggi $(4.98 \mathrm{~kg} / \mathrm{petak})$ dan berbeda nyata dengan perlakuan (G3) dan tanpa perlakuan (G0) tetapi berbeda tidak nyata dengan perlakuan bergulma 20 HST (G1). Gambaran rata-rata produksi dapat dilihat pada gambar 6. 


\section{Median Volume 11 Nomor 2 Bulan Juni 2019}

Doi http://doi.org/md.v11i2.587

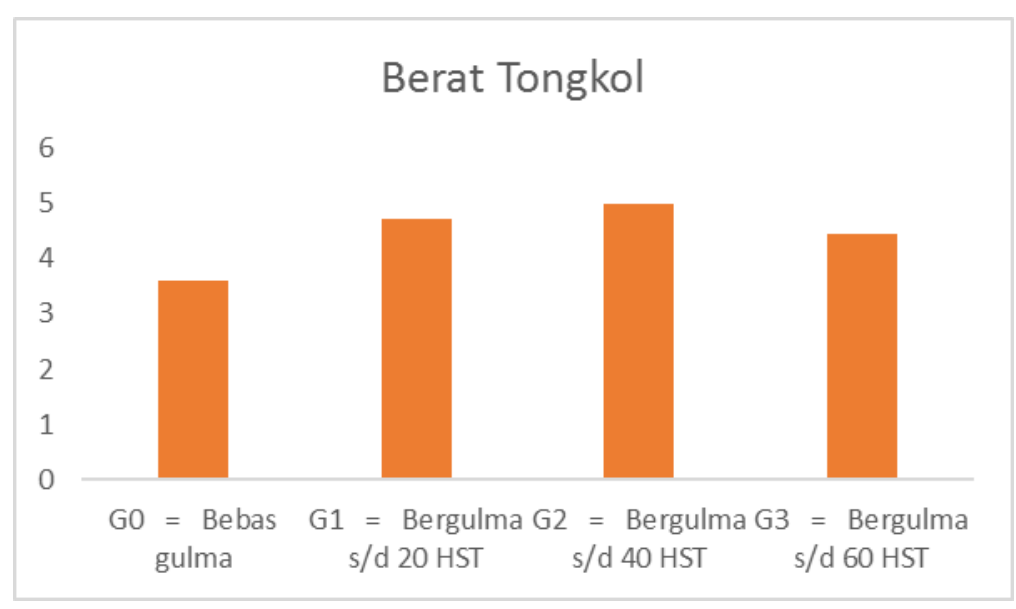

Gambar 6. Rata-rata Produksi Tanaman jagung

\section{Pembahasan}

Gulma dan tanaman pertanian (crops) merupakan tanaman yang secara mendasar keduanya memiliki kebutuhan yang sama untuk tumbuh dan berkembang secara normal. Keduanya juga membutuhkan pasokan yang memadai akan nutrisi-nutrisi yang sama, kelembapan,cahaya, suhu, dan karbon dioksida (CO2). Gulma berhasil bersaing dengan tanaman budidaya dengan menjadi lebih agresif saat tumbuh. Gulma memperoleh dan menggunakan unsur-unsur essensial (nutrisi, kelembapan, cahaya, suhu, dan karbon dioksida) bagi pertumbuhan dan perkembangan tanaman menekan pertumbuhan tanaman budidaya. Selain itu gulma juga memiliki beberapa zat kimia yang dapat menghambat pertumbuhan dan tanaman budidaya Anderson (1977).

Data hasil pengamatan di lapangan dianalisis sesuai dengan perameter engamatan diantaranya : tinggi tanaman, jumlah daun, diameter tongkol, berat tongkol, panjang tongkol, dan roduksi tongkol. Hasil pengamatan menunjukan bahwa pengaruh perlakuan Penyiangan gulma berpengaruh nyata pada tinggi tanaman pada umur 15, 30 dan 45 HST. Hasil analisis ragam pada tinggi tanaman di perlakuan bergulma s/d 20 HST (G1) menghasilkan rata-rata tanaman tertinggi pada umur 15 HST $(97,46 \mathrm{~cm}), 30$ HST $(164,94 \mathrm{~cm})$ dan Umur 45 HST $(223,18 \mathrm{~cm})$ dan berbeda nyaata dengan perlakuan lainnya pada umur 15,30 dan 45 HST, tetapi berbeda tidak nyata pada perlakuan bergulma (G2) dan (G3). Sedangkan Tanaman yang paling rendah terjadi pada tanpa perlakuan (G0) bebas gulma. Hal ini diduga karena penyiangan gulma yang lebih cepat atau lambat akan berpengaruh terhadap pertumbuhan tanaman dalam berkompetisi dalam pengambilan unsure hara. Hal senada seperti yang diungkapkan oleh Sukman dan Yakup (2005) yang menyatakan bahwa penyiangan dapat memberikan hasil jagung manis lebih tinggi apabila dilakukan sesuai umur dan perkembangan tanaman. Penyiangan yang lebih awal dapat mempengaruhi populasi gulma dan hasil tanaman berikutnya sehingga menekan kehilangan hasil pada tanaman jagung manis dan pertumbuhan dan perkembangan tanaman menjadi lebih baik karena tanaman mendapatkan hara, air dan matahari lebih banyak.

Menurut Pertina (2016) dalam laporannya mengatakan pengaruh dari pengendalian dengan melakukan penyiangan gulma akan menyebabkan peningkatan hasil karena adanya kehilangan persaingan dalam mendapatkan cahaya, air, nutrisi, ruang dan lainnya. Namun dengan adanya pengendalian yang terus menerus dapat merusak tanaman karena sentuhan alat akan merusak dan menunrunkan hasil. Maka sangat perlu dilakukan penyiangan dengan waktu-waktu tertentu. 
Sementara perlakuan pengendalian gulma pada pengamatan jumlah daun tanaman jagung manis menunjukan bahwa perlakuan perlakuan bergulma s/d 20 HST (G1) menghasilkan rata-rata jumlah daun terbanyak pada umur 4 MST (8,17 helai), 6 MST (12, 83 helai) dan Umur 8 MST 14,33 helai) tetapi berbeda tidak nyata dengan perlakuan bergulma (G2) dan (G3) pada umur 15, 30 dan 45 HST dan berbeda nyata dengan perlakuan bergulma lainnya dan bebas gulma. Hal ini diduga karena Gulma yang merupakan pesaing bagi tanaman dalam memperoleh hara dapat dikendalikan sedini mungkin sehingga tdk dapat menghambat pertumbuhan dan perkembngan tanaman jagung manis. Menurut Sukman dan Yakup (2002) pengendalian gulma diperlukan oleh sebagian besar tanaman agar mencegah pertumbuhan gulma yang dapat meningkatkan persaingan inter-spesifik antara gulma dan tanaman, sehingga berdampak bagi penurunan hasil yang diperoleh. Selanjutnya Menurut Rudiono (2016) penyiangan gulma untuk menurunkan tingkat kompetisi pada tanaman budidaya dilakukan pada 21 -42 hari setelah pindah tanam.

Hasil pengamatan terhadap komponen generative tanaman jagung manis akibat perlakuan penyiangan gulma berpengaruh terhadap diameter tongkol, panjang tonggkol, berat tongkol dengan klobot dan produksi tongkol. Hasil analisis ragam menunjukan bahwa pengaruh perlakuan penyiangan gulma pada umur 40 HST (G2) menyebabkan diameter tongkol lebih besar $(6.19 \mathrm{~cm})$, dan berbeda nyata dengan tanpa perlakuan (bebas gulma), tetapi tidak beda nyata dengan perlakuan bergulma 20 HST (G1) dan 60 HST (G3). Sedangkan panjang tongkol yang terpanjang sebesar $23.85 \mathrm{~cm}$ dan berbeda nyata dengan perlakuan bebas gulma dan bergulma hingga 20 HST (G3), tetapi tidak beda nyata dengan perlakuan bergulma hingga 40 HST (G3) dan berbeda nyata perlakuan bergulmam lainnya, tetapi tidak berbeda nyata dengan perlakuan bergulma (G1). Hal ini disebabkan karena penyiangan gulma menjadi faktor penting dalam budidaya tanaman sehingga produksi tanaman jagung manis menjadi lebih besar. Hal tersebut seperti disampaikan oleh Moenandir (2003), bahwa pengaruh penyiangan gulma yang berada di sekitar tanaman budidaya akan menjadi indikatorr yang dapat mempengaruhi proses pertumbuhan dan hasil tanaman jika dilakukan sesuai dengan umur dan waktu yang sangat tepat. Sedangkan Menurut Rusmanto (2012) frekuensi penyiangan gulma dalam waktu yang tidak terlalu lama terhadap tanaman dengan tepat waktu akan menghindari terjadinya kompetisi antara gulma dengan tanaman utama sehingga produksi diameter dan panjang tongkol yang dihasilkan akan lebih baik.

Selanjutnya perlakuan penyiangan gulma hingga 40 HST (G2) berpengaruh terhadap berat tongkol (125.75 g) dan berbeda nyata dengan perlakuan bergulma lainnya dan tanpa perlakuan (G0), sedangkan perlakuan bergulma 60 HST (G3) dan 20 HST (G1) berbeda tidak nyata. Sedangkan perlakuan bergulma s/d 40 HST (G2) memberikan hasil rata-rata produksi tanaman tertinggi $(4.98 \mathrm{~kg} /$ petak) dan berbeda nyata pada perlakuan (G3) dan tanpa perlakuan (G0) tetapi berbeda tidak nyata pada perlakuan bergulma 20 HST (G1). Hal tersebut menunjukan bahawa semakin sering penyiangan dilakukan maka pertumbuhan gulma akan semakin tertekan sehingga persaingan dalam pengambilan unsur hara tidak terjadi dan hasil produksi gabah akan meningkat. Menurut Septrina (2008) dengan melakukan penyiangan akan memperoleh buah lebih besar jika dibandingkan dengan tidak melakukan penyiangan. Hal yang sama terjadi pada Simamora (2008) kehilangan hasil pada tanaman jagung dapat terjadi jika tidak dilakukan penyiangan gulma sebesar 44,03\% dibandingkan dengan tanaman jagung yang bebas gulma. Frekuensi penyiangan gulma dengan disiangi 2 kali dalam 40 hari sangat efektif mengendalikan gulma sehingga dapat menekan pertumbuhannya 
serta kompetisi antara gulma dengan tanaman padi dapat terhindari dalam memperebutkan tempat tumbuh, unsur hara, cahaya dan air.

Rata rata hasil terendah dari variabel pengamatan yang diamati diperoleh dari perlakuan bebas gulma atau tanpa perlakuan (G0) kondisi ini disebabkan karena gulma yang dibiarkan bebas tumbuh dengan tanaman jagung akan menjadi yang akan menimbulkan adanya kompetisi antara tanaman dengan gulma. Rusmanto (2012) menyatakan bahwa keberadaan gulma yang tinggi pada areal budidaya akan menurunkan produksi sebanyak produksi sebanyak $76.6 \%$. Dengan tidak dilakukannnya penyiangan maka akan meningkatkan pertumbuhan gulma dan menimbulkan persaingan hara antara gulma dan tanaman. Pendapat lain dari Jatmiko et al. (2002) menyatakan persaingan mendapatkan beberapa faktor tumbuh yang terbatas, seperti cahaya, hara dan air terjadi antara gulma dan tanaman. Menurut Fadli et al (2013) penyiangan pada tanaman budidaya harus dilakukan dengan cepat untuk menghindari terhambatnya pertumbuhan tanaman karena terjadinya perebutan unsur hara.

\section{KESIMPULAN}

1. Perlakuan gulma (G1) berpengaruh nyata terhadap tanaman saat pertumbuhan vegetatif dan perlakuan (G2) berpengaruh nyata terhadap tanaman jagung manis pada saat pertumbuhan generative tanaman jagung manis.

2. Perlakuan penyiangan gulma (G1) pada tanaman jagung manis hingga waktu sampai dengan 20 hari setelah tanam (HST) berpengaruh terhadap tinggi tanaman jagung manis umur 15 HST $(97.46 \mathrm{~cm}), 30$ HST $(164.94 \mathrm{~cm})$ dan 45 HST $(223.18$ $\mathrm{cm}$ ) dan jumlah daun pada umur 15 HST (18.17 helai), 30 HST (12.83 helai) dan 45 HST (14.33 helai). Sedangkan perlakuan bergulma (G2) hingga waktu 40 hari setelah tanam (HST) berpengaruh terhadap komponen dimeter tongkol $(6.19 \mathrm{~cm})$, panjang tongkol $(23.85 \mathrm{~cm})$, berat tongkol (125.75 gr) dan produksi tongkol (4.98 $\mathrm{kg} /$ petak)

\section{DAFTAR PUSTAKA}

Direktorat Jenderal Perkebunan. 2006. Pedoman pengendalian tumbuh tumbuhan pengganggu. Direktorat Jenderal Perkebunan, Jakarta.

Fadhly, A.F., R. Efendi, M. Rauf, dan M. Akil. 2004. Pengaruh cara penyiangan lahan dan pengendalian gulma terhadap pertumbuhan dan hasil jagung pada tanah bertekstur berat. Seminar Mingguan Balai Penelitian Tanaman Serealia, Maros,

Pertina, Y. 2016. Pengaruh Penyiangan Gulma Terhadap Pertumbuhan Kacang Tanah (Arachis hypogaea L.) Program Studi Agroteknologi,Fakultas Pertanian,Universitas PGRI Yogyakarta.

Rudiono, 2016. Pengaruh Frekuensi Penyiangan Gulma Terhadap Pertumbuhan Dan HAsil Beberapa Varietas Padi Sawah (Oryza sativa L.). Departemen Agronomi dan Hortikultura Fakultas Pertanian Institut Pertanian Bogor 2016.

Rizal, A. 2004. Penentuan kehilangan hasil tanaman akibat gulma. Dalam: S.

Rusmanto. 2012. Studi Potensi Kompetisi Beberapa Aksesi Gulma Jajagoan (Echinochloa crus-galli L) Terhadap Pertumbuhan dan Produksi Padi Hibrida [Skripsi]. Bogor (ID) : Departemen Agronomi dan Hortikultura. Institut Pertanian Bogor. 30 hal 
Tjitrosemito, A.S. Tjitrosoedirdjo, dan I. Mawardi (Eds.) Prosiding Konferensi Nasional XVI Himpunan Ilmu Gulma Indonesia, Bogor, 15-17 Juli 2003. 2: 105-118.

Septrina G. 2008. Pengaruh Waktu dan Cara Pengendalian Gulma Terhadap Pertumbuhan dan Hasil Padi Hibrida (Oriza Sativa, L) [Skripsi]. Bogor (ID) : Departemen Agronomi dan Hortikultura. Institut Pertanian Bogor. 35 hal.

Simomora T.J.L. 2008. Pengaruh Waktu dan Jarak Tanam Terhadap Pertumbuhan dan Produksi Tanaman Jagung (Zea mays, L) Varietas DK3. [Skripsi]. Medan (ID) : Departemen Budidaya Pertanian. Universitas Sumatra Utara. 40 hal.

Sukman, Y. dan Yakup. 2005. Gulma dan Teknik Pengendaliannya. PT Raja Grafindo Persada. Jakarta.. 